\title{
KONDISI KUALITAS AIR DAN RESPONS PERTUMBUHAN PADA PEMELIHARAAN POSTLARVA UDANG VANAME Litopenaeus vannamei MENGGUNAKAN SUMBER ENERGI SURYA
}

\author{
WATER QUALITY CONDITION AND GROWTH RESPONSE ON VANAME SHRIMP \\ Litopenaeus vannamei POSTLARVA REARING BY USING SOLAR ENERGY
}

\author{
Kukuh Adiyana1), Rahma Vida Anandasari' $^{2)}$, Tuti Wahyuni ${ }^{3)}$, dan Lolita \\ Thesiana ${ }^{1)}$ \\ ${ }^{1)}$ Pusat Penelitian dan Pengembangan Perikanan - Badan Penelitian dan Pengembangan kelautan dan \\ Perikanan, Jl Pasir Putih I Ancol, Jakarta, Indonesia \\ ${ }^{2)}$ Departemen Budidaya Perairan Fakultas Perikanan dan Ilmu Kelautan IPB, Jl Raya Dramaga, Bogor, \\ 16680, Indonesia \\ ${ }^{3)}$ Pusat Penelitian dan Pengembangan Daya Saing Produk dan Bioteknologi Kelautan dan Perikanan, - \\ Badan Penelitian dan Pengembangan kelautan dan Perikanan, Jl.Petamburan VI, Jakarta \\ E-mail: k_adiyana@yahoo.com
}

Diterima tangga: 25 Maret 2015, diterima setelah perbaikan12 Januari 2017 disetuji tanggal:16 Januari 2017

\begin{abstract}
ABSTRAK
Sampai saat ini, Indonesia masih mengandalkan sumber energi PLN dalam memenuhi kebutuhan energi listrik, baik untuk kebutuhan masyarakat maupun industri seperti budidaya perairan. Energi listrik pada budidaya perairan sangat dibutuhkan untuk menggerakkan pompa aerasi dalam menyediakan oksigen terlarut.Pada Sumber energi PLN seringkali terjadi pemadaman listrik mendadak, yang dapat menyebabkan kerugian besar bagi pembudidaya. Energi surya merupakan salah satu alternatif energi terbarukan yang berpotensi untuk digunakan dalam kegiatan budidaya postlarva udang vaname Litopenaeus vannamei.Tujuan dari penelitian ini adalah untuk menguji kondisi kualitas air dan respons pertumbuhan pada pemeliharaan postlarva udang vaname dengan menggunakan sumber energi surya. Pada Penelitian ini digunakan 2 perlakuan, yaitu perlakuan menggunakan sumber energi surya dan PLN. Hasil penelitian menunjukkan, penggunaan sumber energi surya pada pemeliharaan postlarva udang vaname tidak berpengaruh terhadap kondisi kualitas air dan respons pertumbuhan udang. Hal ini disebabkan pemadaman listrik oleh PLN hanya menyebabkan penurunan konsentrasi DO sampai $6,8 \mathrm{mg} / \mathrm{L}$, dimana pada konsentrasi ini respons pertumbuhan udang dan degradasi bahan organik (sisa pakan, feces) oleh mikroorganisme masih dalam kondisi optimal.
\end{abstract}

Kata Kunci :Energi surya,PLN, udang vaname, kualitas air ,respons pertumbuhan.

\section{ABSTRACT}

Currently Indonesia still relies on PLN to fulfill the electrical demand, both household and industrial needs such as aquaculture. Electrical energy in aquaculture is needed for aeration to provide dissolved oxygen for cultured comodities. A sudden power outage was the disadvantage of relying main energy source on PLN. Power failure can lead farmer great lost, this would't be happened if farmers have a energy source backup for aquaculture. Solar energy is potential renewable energy alternatives used in aquaculture activities for rearing Litopenaeus vannamei postlarva. The aim of this study was to analyse water quality conditions and shrimp postlarva

Kondisi Kualitas Air Dan Respons Pertumbuhan Pada Pemeliharaan Postlarva Udang Vaname Litopenaeus Vannamei Menggunakan Sumber Energi Surya - Kukuh Adiyana, Rahma Vida Anandasari, Tuti Wahyuni, dan Lolita Thesiana 
growth response during rearing periode by using solar energy sources. This study used two treatments, solar energy sources and PLN energy sources. The results showed that solar energy resources using in rearing vaname shrimp postlarva didn't affect water quality and shrimp growth response. PLN power outage decrease DO concentration to $6.8 \mathrm{mg} / \mathrm{L}$, in which at this concentration response shrimp growth and degradation of organic matter (residual feed, feces) by microorganisms were still at optimum condition.

Keywords : Solar energy, vaname shrimp, water quality, growth response.

\section{PENDAHULUAN}

Udang vaname Litopenaeus vannamei adalah salah satu komoditas perikanan yang mempunyai nilai ekonomi tinggi. Permintaan pasar baik dalam maupun luar negeri terhadap udang vaname mengalami peningkatan setiap tahunnya. Amerika serikat adalah salah satu negara pengimpor utama, dengan nilai impor di tahun 2011 sebesar 576.000 ton, setara dengan USD 5,1 miliar (Li et al. 2014). Produksi budidaya udang vaname dunia mengalami peningkatan pesat, yaitu sebesar 2.720.929 ton pada tahun 2010 (FAO, 2012). Potensi yang sangat besar tersebut, menyebabkan perlunya dilakukan pengembangan budidaya udang vaname secara intensif.

Budidaya postlarva udang vaname dengan kepadatan tinggi pada sistem intensif/ super intensif memerlukan energi yang cukup besar, utamanya untuk proses pengelolaan kualitas air seperti aerasi. Aerasi dimaksudkan untuk meningkatkan luas permukaan antara udara dan air, meningkatkan oksigen transfer dan sekaligus memberikan sirkulasi untuk mencegah terjadinya stratifikasi dalam pengelolaan kualitas air (Kumar et al. 2013). Dewasa ini kebutuhan energi (listrik) yang diperlukan pada kegiatan budidaya masih terkendala dengan kontinuitas dan ketersediaan pasokan. Seringkali kegiatan budidaya perikanan mengalami kendala pasokan listrik karena adanya pemadaman listrik dari PLN secara mendadak. Hal lainnya adalah belum terjangkaunya aliran listrik pada daerah-daerah terpencil. Selama ini daerah yang terpencil, kebutuhan listriknya bergantung pada genset dengan bahan bakar minyak. Penggunaan bahan bakar minyak seringkali mengalami kendala karena harga yang sering mengalami fluktuasi dan kelangkaan pasokan.

Dewasa ini telah banyak dikembangkan teknologi-teknologi yang mampu menyediakan energi listrik yang bersumber dari sumber-sumber energi terbarukan. Menurut Fara dan Yamaguchi (2013), beberapa sumber energi terbarukan di dunia yang mempunyai potensi untuk dimanfaatkan adalah tenaga hidro elektrik (4,6 TW), Panas bumi (30 TW), energi laut (2,7 TW), energi angin (50 TW), dan energi surya $\left(1,2 \times 10^{5} \mathrm{TW}\right)$. Energi surya merupakan sumber energi terbarukan yang mempunyai potensi paling besar untuk dimanfaatkan. Pancaran cahaya matahari mencapai bumi sekitar 3,9 × $10^{6}$ EJ per tahun (Moheimani dan Parlevliet 2013). Ketersediaan energi surya khususnya di daerah pesisir di indonesia sangat melimpah. Hal ini menunjukkan energi surya dapat digunakan sebagai alternatif sumber energi untuk mendukung kegiatan perikanan.

Pemanfaatan energi radiasi matahari dapat dilakukan dengan menggunakan sistem konversi fotovoltaik melalui suatu piranti optoelektronik yang disebut sel surya (solar cell). Sel surya merupakan salah satu sumber energi alternatif dan dapat mengkonversi secara langsung energi matahari menjadi energi listrik. Menurut Bakhiyi et al. (2014), Aplikasi penggunaan sel surya dunia mempunyai kapasitas bervariasi dari 1,4 GW pada tahun 2000 menjadi 102 GW di tahun 2012. Penggunaan sel surya terbesar terdapat di Eropa (>70 GW), kemudian diikuti oleh Cina $(8,3 \mathrm{GW})$, Amerika Serikat $(7,7 \mathrm{GW})$, dan Jepang $(6,9 \mathrm{GW})$. Selama kurun waktu antara akhir tahun 2007 sampai dengan 2012, pertumbuhan produksi sel 
surya meningkat sebesar $60 \%$. Hal ini cukup tinggi jika dibandingkan dengan pemanfaatan energi terbarukan lainnya yang bersumber dari energi angin $(25 \%)$ dan hidroelektrik (3,3\%) (REN, 2013). Peningkatan pertumbuhan produksi sel surya ini karena dari sisi ekonomi harganya sangat bersaing. Pada akhir tahun 2001, harga modul surya adalah 5,5 US\$/ Wp (Solarbuzz, 2012) kemudian mengalami penurunan kurang dari 1 US\$/ Wp pada desember 2013. Hal inilah yang mendasari, bahwa penggunaan teknologi panel surya diharapkan dapat menjawab beberapa permasalahan kelangkaan energi, khususnya untuk kegiatan budidaya perikanan.

Tujuan dari penelitian ini adalah untuk menguji kondisi kualitas air dan respons pertumbuhan pada pemeliharaan postlarva udang vaname Litopenaeus vannamei dengan menggunakan sumber energi surya.

\section{BAHAN DAN METODE}

Bahan yang digunakan pada penelitian ini adalah udang vaname (PL 10) dengan panjang rata-rata $0,87 \pm 0,09 \mathrm{~cm}$ dan bobot rata-rata 0,003 gram; air laut; sodium sulfit $\left(\mathrm{Na}_{2} \mathrm{SO}_{3}\right)$; dan pakan udang protein $30 \%$. Alat yang digunakan pada persiapan serta penelitian ini adalah 4 bak fiber kapasitas 500 liter, rangkaian panel surya, aerator jenis high-blow, dan DO meter.

\section{Persiapan Sistem Pemeliharaan}

Persiapan sistem pemeliharaan terdiri dari persiapan wadah, instalasi listrik dan aerasi, dan bahan. Setiap bak pemeliharaan dipasang 4 buah selang aerasi yang dihubungkan pada high-blow. Air yang dijadikan media pemeliharaan adalah air laut dengan salinitas 30 ppt. Air sebanyak 500 liter yang telah dimasukkan ke dalam bak fiber pemeliharaan di-treatment dengan 30 ppm klorin dan diaerasi kuat, setelah 24 jam kemudian air diberi tiosulfat dengan dosis 15 ppm dan diaerasi kuat selama 24 jam. Sebelum digunakan, bagian dasarnya disipon terlebih dahulu.

Instalasi listrik tenaga surya dirangkai secara parallel yang meliputi: 8 papan panel dengan kapasitas setiap panel 100 watt peak, 12 Volt; 4 charge controller dengan kapasitas setiap charge controller 12 Volt, 20 Ampere; dan 8 aki (baterai) dengan kapasitas setiap aki 100 Ampere hour, 12 Volt. Energi matahari yang ditangkap panel dalam bentuk arus searah (DC) akan disimpan di dalam aki melalui charge controller. Arus listrik dalam aki dialirkan ke high-blow melalui inverter yang berfungsi sebagai pengubah arus serarah (DC) menjadi bolak-balik (AC). Sebanyak 8 buah aki dipasang secara paralel dan dihubungkan pada 1 aerator high-blow. Instalasi listrik yang menggunakan sumber energi PLN 220 Volt; langsung dihubungkan dengan aerator high-blow. Instalasi listrik dan bak pemeliharaan dapat dilihat pada Gambar 1. 


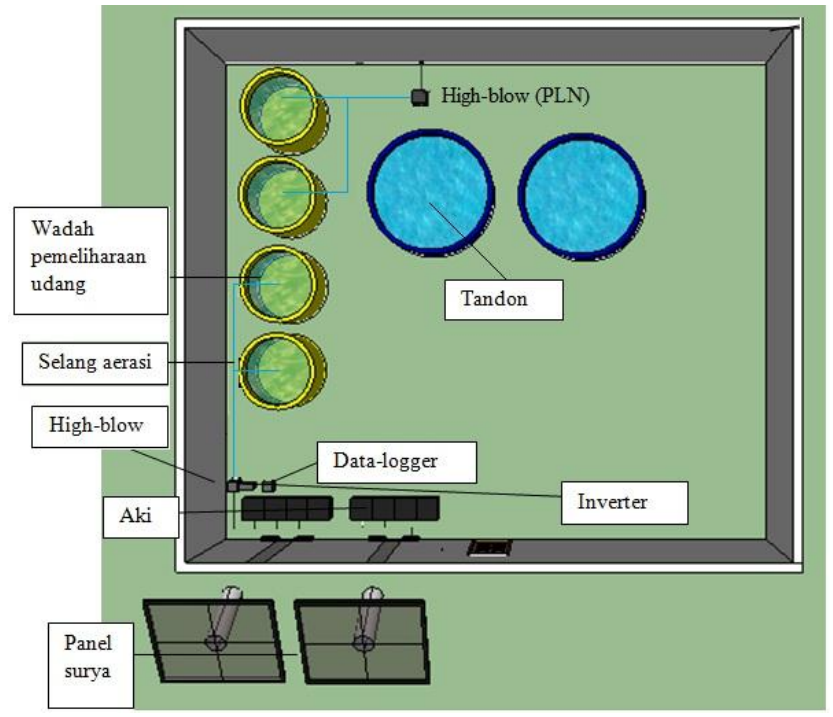

(a)

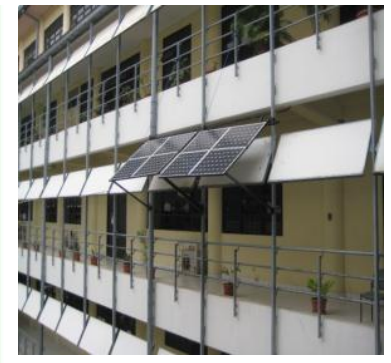

(b)

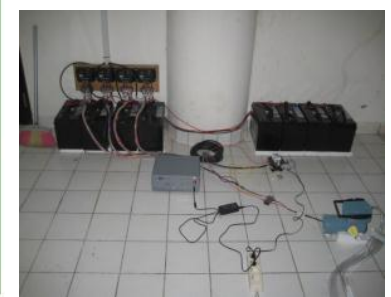

(d)

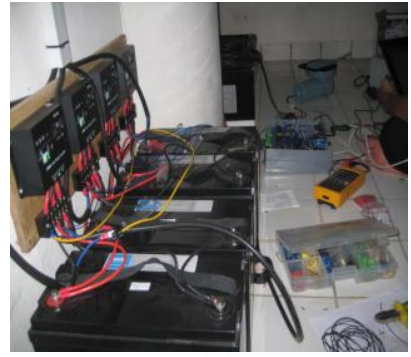

(c)

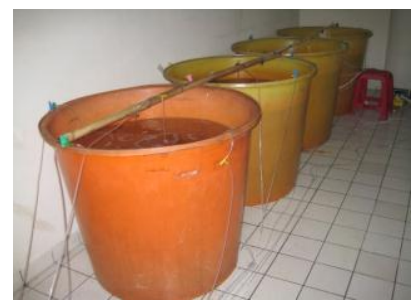

(e)

Gambar 1 Skema bak pemeliharaan dan instalasi listrik (a); panel surya (b); aki (c); rangkaian aki, data logger dan pompa aerator hi-blow (d); bak pemeliharaan (e) (sumber: dokumentasi pribadi).

Figure $1 \quad$ Reared pool and electrical installation scheme (a); solar panel (b); battery (c); batteries circuit, data logger and hi-blow aerator pump (d); reared pool (e) (source: personal documentation).

\section{Pemeliharaan}

Pemeliharaan terdiri dari penebaran benih, pemberian pakan, dan pengelolaan kualitas air. Biota yang digunakan adalah udang vaname PL10. Udang ini dipelihara selama 20 hari dengan padat tebar $200 \mathrm{ekor} / \mathrm{m}^{3}$ (Samocha dan Lawrence 1992). Pemeliharaan udang dilakukan selama 20 hari. Pemberian pakan udang dilakukan 4 kali, yakni pada pukul 07.00, 12.00, 17.00, dan 22.00 WIB, sesuai dengan persentase biomassa 25-45\% (Nuhman, 2009). Pakan yang diberikan adalah pakan powder dengan kadar protein $30 \%$. Setiap pemberian pakan diberikan dosis 2 ppm. Pergantian air dilakukan setiap 2 hari, sekali sebanyak 10$15 \%$ sekaligus dilakukan penyifonan.

\section{Rancangan Penelitian}

Rancangan penelitian menggunakan rancangan acak lengkap (RAL) dengan 2 perlakuan dan 2 ulangan. Jenis perlakuan yaitu penggunaan high-blow dengan sumber energi surya dan sumber energi PLN. Parameter penelitian yang diuji adalah oksigen terlarut (DO), suhu, $\mathrm{pH}$, total amoniak nitrogen (TAN), $\mathrm{CO}_{2}$, salinitas, tingkat kelangsungan hidup (SR), dan bobot postlarva. Parameter DO, suhu, $\mathrm{pH}$, dan salinitas diukur menggunakan alat ukur kualitas air merek YSI tipe 556 MPS. TAN danCO $\mathrm{C}_{2}$ dianalisa menggunakan metode APHA (1990). Perhitungan SR dan laju pertumbuhan spesifik mengacu pada Solanki et al. (2012). Pengukuran parameter DO dan suhu dilakukan setiap hari, sedangkan $\mathrm{pH}$, $\mathrm{CO}_{2}$, total amoniak nitrogen (TAN), dan salinitas dilakukan 7 hari sekali. Tingkat kelangsungan hidup dan bobot postlarva diukur pada awal dan akhir penelitian. 


\section{HASIL DAN PEMBAHASAN}

\section{Hasil}

Kualitas air

Oksigen terlarut (DO)

Oksigen terlarut DO) dibutuhkan oleh semua jasad hidup untuk pernapasan, proses metabolisme, atau pertukaran zat yang kemudian menghasilkan energi

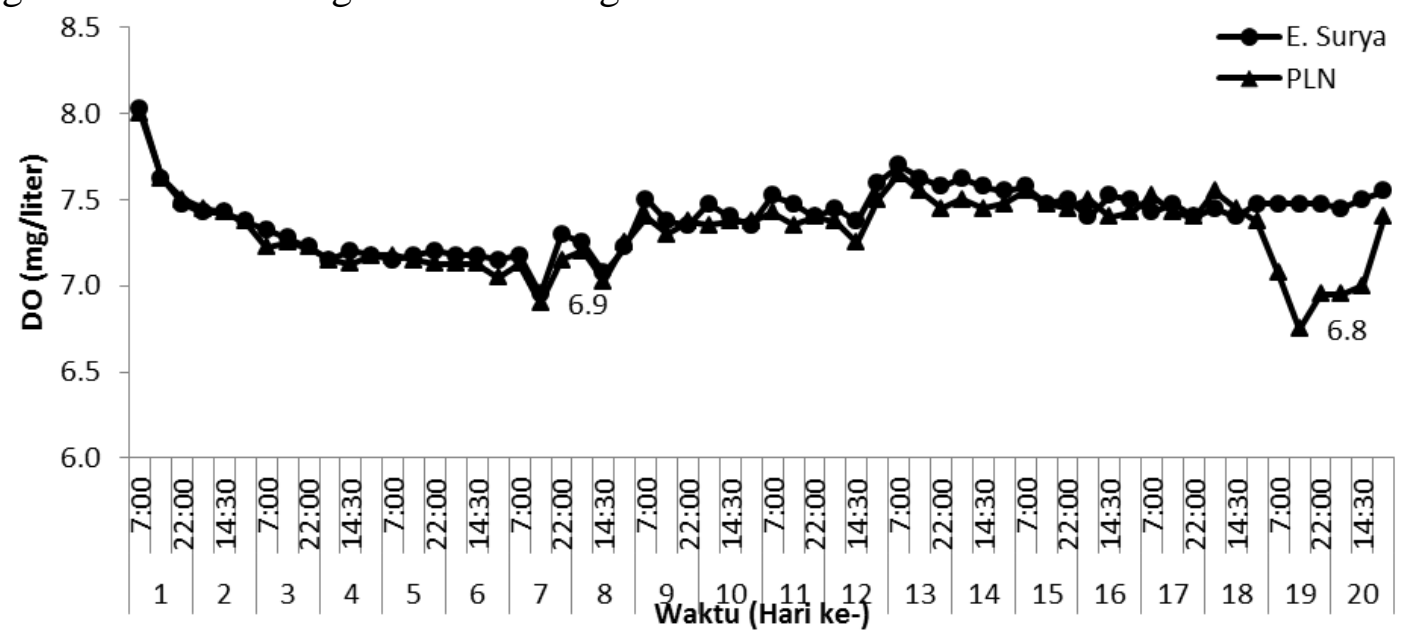

untuk pertumbuhan dan pembiakan. Di samping itu, oksigen juga dibutuhkan untuk mengoksidasi bahan-bahan organik dan anorganik dalam proses aerobik. Kondisi oksigen terlarut selama penelitian dapat dilihat pada Gambar 2 dan 3.

Gambar 2. Kondisi DO harian pada media pemeliharaan udang vaname.

Figure 2 Daily DO conditions in rearing vaname shrimp.

Nilai DO harian pada kedua perlakuan hampir sama. DO harian pada high-blow yang menggunakan sumber energi surya berkisar antara 7-8 $\mathrm{mg} /$ Liter sedangkan DO pada high-blow yang menggunakan PLN berkisar antara 6,8-8 mg/Liter (Gambar 2).

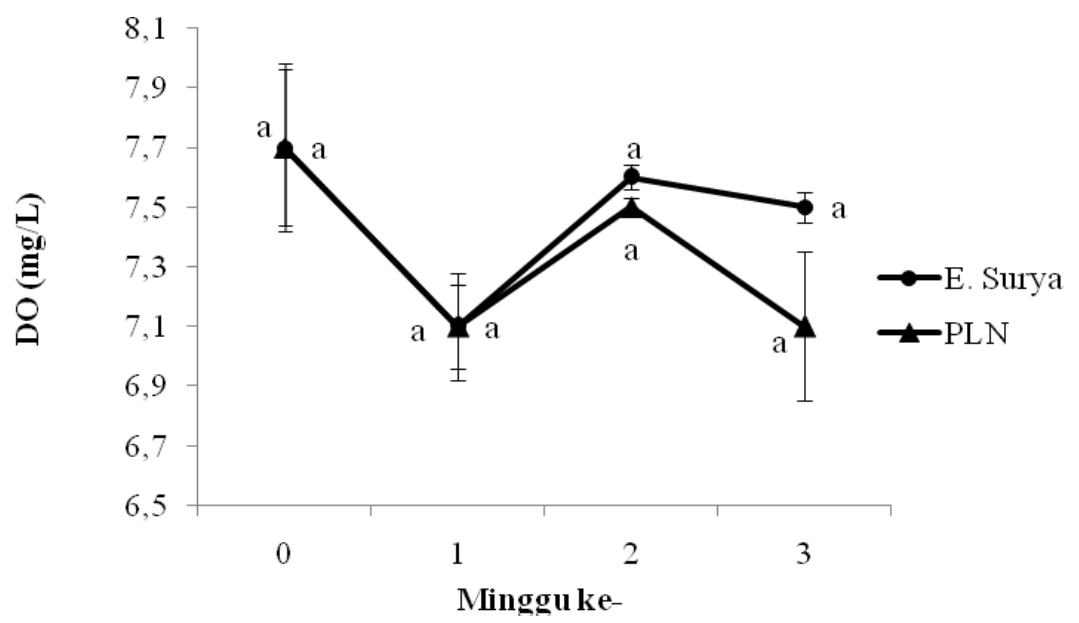

Gambar 3. Kondisi DO mingguan rata-rata pada media pemeliharaan udang vaname menggunakan sumber energi yang berbeda. Huruf kecil yang berbeda dalam grafik menunjukkan beda nyata $(\mathrm{p}<0,05)$.

Kondisi Kualitas Air Dan Respons Pertumbuhan Pada Pemeliharaan Postlarva Udang Vaname Litopenaeus Vannamei Menggunakan Sumber Energi Surya - Kukuh Adiyana, Rahma Vida Anandasari, Tuti Wahyuni, dan Lolita Thesiana 
Figure 3 Average weekly DO conditions in rearing vaname shrimp throughout the study. Different lowercase in the graph indicate significant difference $(p<0.05)$.

DO yang menggunakan sumber energi surya maupun PLN mengalami penurunan pada minggu ke-1 berturut-turut dari $7,7 \pm 0,28 \quad \mathrm{mg} /$ Liter menjadi $7,1 \pm 0,18$ $\mathrm{mg} /$ Liter dan dari $7,7 \pm 0,26 \mathrm{mg} / \mathrm{Liter}$ menjadi 7,1 $\pm 0,14 \mathrm{mg} /$ Liter (Gambar 3). Pada minggu ke-2, DO dari perlakuan sumber energi surya naik menjadi $7,6 \pm 0,04$ $\mathrm{mg} / \mathrm{Liter}$, sedangkan pada perlakuan sumber energi PLN, DO naik menjadi 7,5 $\pm 0,03 \mathrm{mg} /$ Liter. Pada minggu ke-3, DO perlakuan sumber energi surya hanya turun hingga 7,5 $\pm 0,05 \mathrm{mg} /$ Liter, sedangkan pada perlakuan sumber energi PLN turun hingga

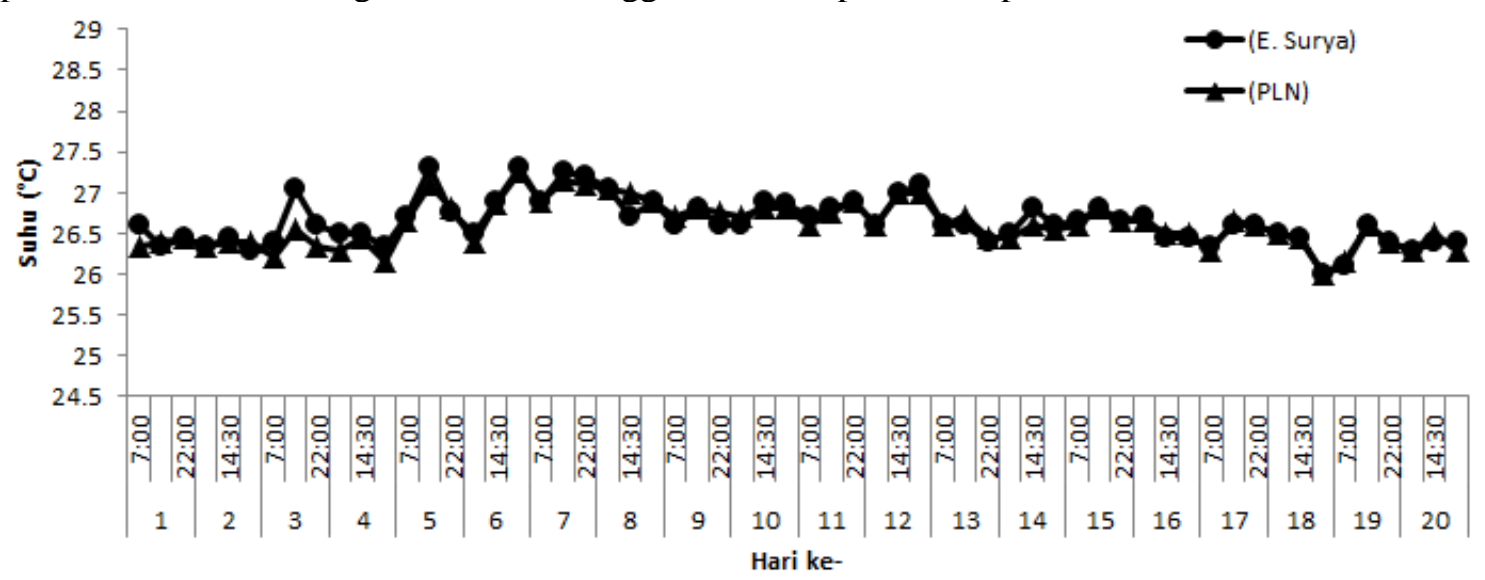

Gambar 4 Kondisi suhu harian pada media pemeliharaan udang vaname.

Figure 4 Daily water themperature condition during vaname shrimp rearing

Kondisi suhu harian pada kedua perlakuan mempunyai tren yang relatif sama. Setiap harinya suhu media dengan perlakuan sumber energi surya dan PLN berkisar menjadi 7,1 $\pm 0,25 \mathrm{mg} /$ Liter. Hasil analisis ragam menunjukkan, perlakuan dengan sumber energi yang berbeda, tidak berbeda nyata $(p>0,05)$ terhadap kondisi DO selama pemeliharaan.

\section{Suhu}

Suhu suatu perairan sangat dipengaruhi oleh jumlah cahaya matahari yang jatuh ke permukaan perairan, sebagian dipantulkan kembali ke atmosfer dan sebagian masuk ke perairan yang disimpan dalam bentuk energi. Kondisi suhu selama penelitian dapat dilihat pada Gambar 4. antara 26,0 sampai dengan $27,3 \quad{ }^{\circ} \mathrm{C}$ (Gambar 4). 


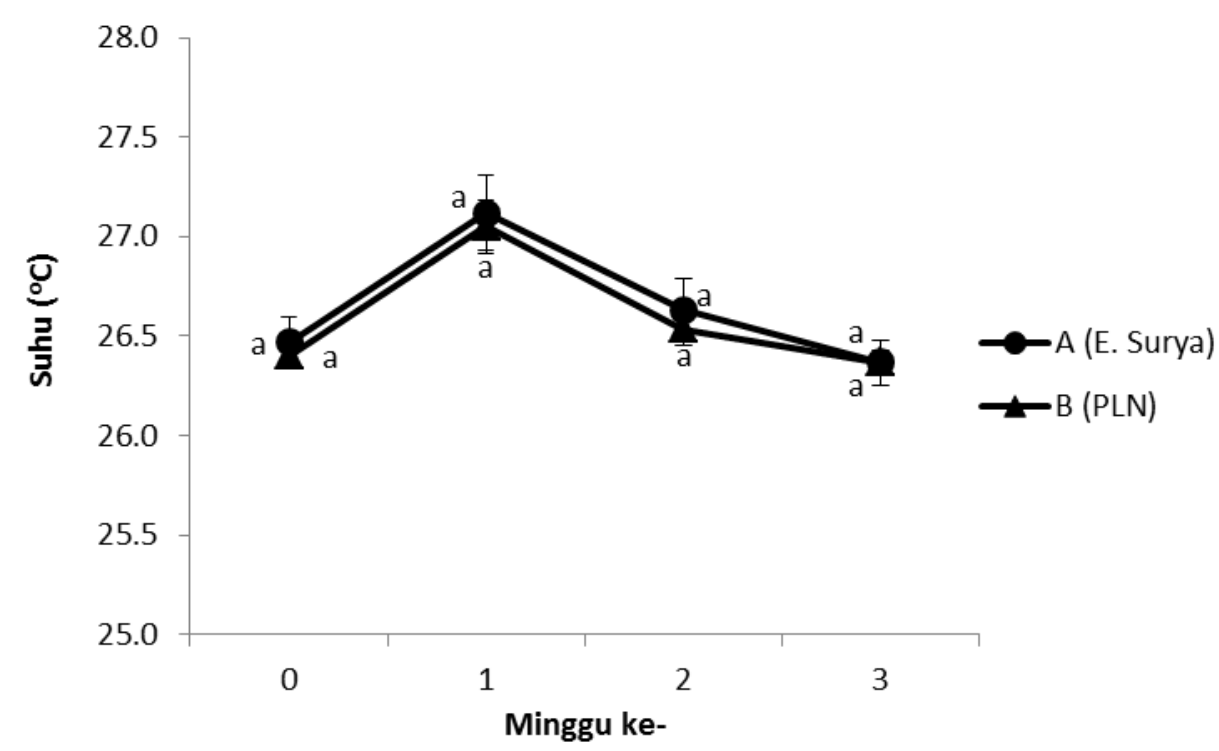

Gambar 5. Suhu mingguan rata-rata pada media pemeliharaan udang vaname menggunakan sumber energi yang berbeda. Huruf kecil yang berbeda dalam grafik menunjukkan beda nyata $(\mathrm{p}<0,05)$.

Figure 5. Weekly water themperature average during vaname rearing used different energy source. Different lowercase letters in the graph indicates significant difference ( $p$ $<0.05$ ).

Berdasarkan pengamatan suhu mingguan rata-rata, dapat diketahui bahwa suhu pada kedua perlakuan mengalami kenaikan pada minggu ke-1 kemudian mengalami penururunan sampai akhir pengamatan . Hasil analisis ragam menunjukkan, perlakuan dengan sumber energi yang

berbeda, tidak berbeda nyata $(p>0,05)$ terhadap kondisi suhu selama pemeliharaan.

\section{$\mathrm{CO}_{2}$, salinitas, $\mathrm{pH}$ dan $\mathrm{NH}_{3}$}

Pengukuran kualitas air berupa parameter $\mathrm{CO}_{2}$ dan salinitas dapat dilihat pada Tabel 1 . Sedangkan pengukuran $\mathrm{pH}$ dan $\mathrm{NH}_{3}$ dapat dilihat pada Gambar 6 dan Gambar 7.

Tabel $1 \mathrm{CO}_{2}$ dan salinitas pada air pemeliharaan udang vaname

Tabel $1 \mathrm{CO}_{2}$ and salinity in water during vaname shrimp rearing

Keterangan:

\begin{tabular}{ccccccccc}
\hline $\begin{array}{c}\text { Minggu } \\
\text { ke- }\end{array}$ & \multicolumn{4}{c}{$\mathrm{CO}_{2}(\mathrm{mg} / \mathrm{Liter})$} & \multicolumn{4}{c}{ Salinitas (ppt) } \\
\cline { 2 - 9 } & $\mathrm{A} 1$ & $\mathrm{~A} 2$ & $\mathrm{~B} 1$ & $\mathrm{~B} 2$ & $\mathrm{~A} 1$ & $\mathrm{~A} 2$ & $\mathrm{~B} 1$ & $\mathrm{~B} 2$ \\
\hline 0 & 0 & 0 & 0 & 0 & 30 & 30 & 30 & 30 \\
1 & 0 & 0 & 0 & 0 & 29 & 30 & 29 & 29 \\
2 & 0 & 0 & 0 & 0 & 30 & 30 & 30 & 30 \\
3 & 0 & 0 & 0 & 0 & 30 & 30 & 30 & 30 \\
\hline
\end{tabular}

A $=$ Sumber energi surya

$\mathrm{B}=$ Sumber energi PLN

Kondisi $\mathrm{CO}_{2}$ dan salinitas selama penelitian tidak berbeda nyata $(p>0,05)$ antar perlakuan. Level $\mathrm{CO}_{2}$ dengan perlakuan sumber energi surya maupun sumber energi PLN selama penelitian adalah $0 \mathrm{mg} /$ Liter. Salinitas pada semua perlakuan berkisar antara 29 sampai dengan 30 ppt.

Kondisi Kualitas Air Dan Respons Pertumbuhan Pada Pemeliharaan Postlarva Udang Vaname Litopenaeus Vannamei Menggunakan Sumber Energi Surya - Kukuh Adiyana, Rahma Vida Anandasari, Tuti Wahyuni, dan Lolita Thesiana 


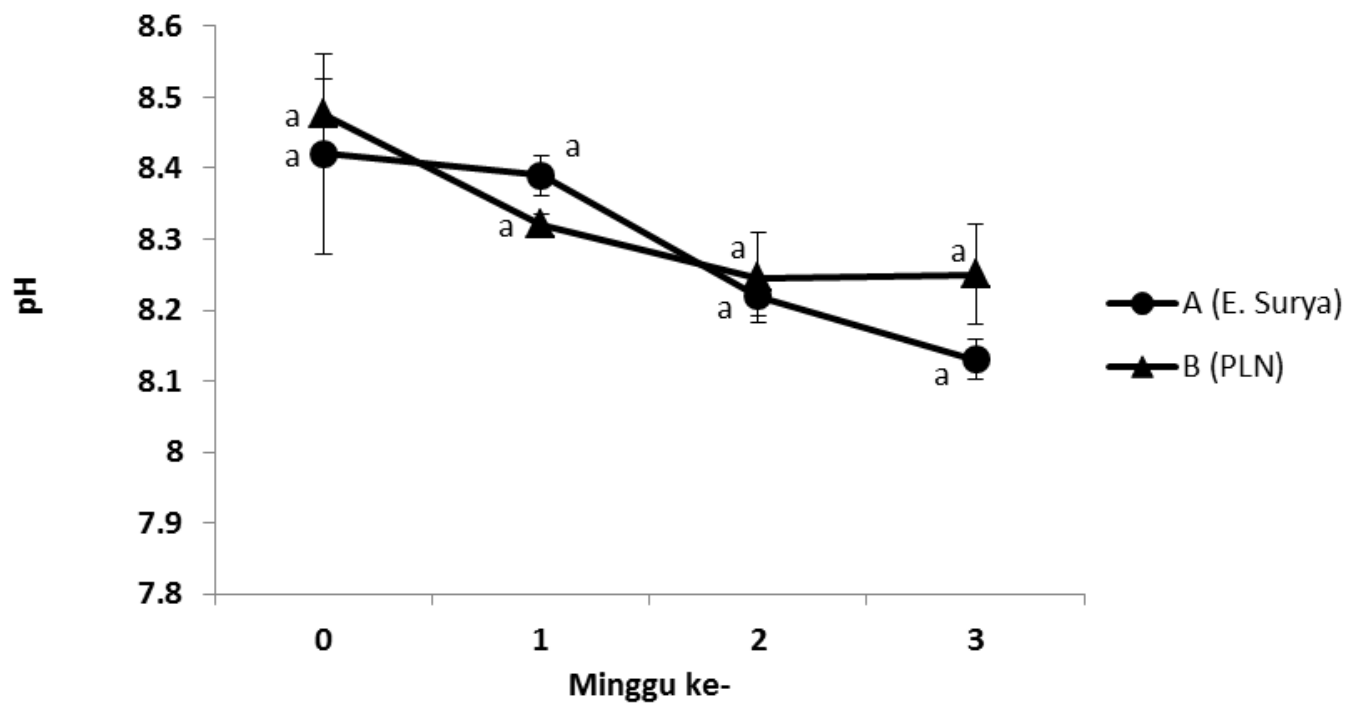

Gambar 6. Grafik pH media pemeliharaan udang vaname pada minggu ke-0, 1, 2, dan 3 dengan sumber energi yang berbeda. Huruf kecil yang berbeda dalam grafik menunjukkan beda nyata $(\mathrm{p}<0,05)$.

Figure $6 \quad$ Graph of $\mathrm{pH}$ in water during vaname shrimp rearing at 0, 1, 2, and 3 weeks with different energy sources. Different lowercase letters in the graph indicates significant difference $(p<0.05)$.

Berdasarkan Gambar 6, dapat diketahui secara umum $\mathrm{pH}$ pada kedua perlakuan mengalami penurunan. Meskipun demikian, kedua $\mathrm{pH}$ masih di atas nilai 8 . Nilai $\mathrm{pH}$ air dari perlakuan sumber energi surya berangsur mengalami penurunan hingga $8,13 \pm 0,028$ (minggu ke-3), sedangkan $\mathrm{pH}$

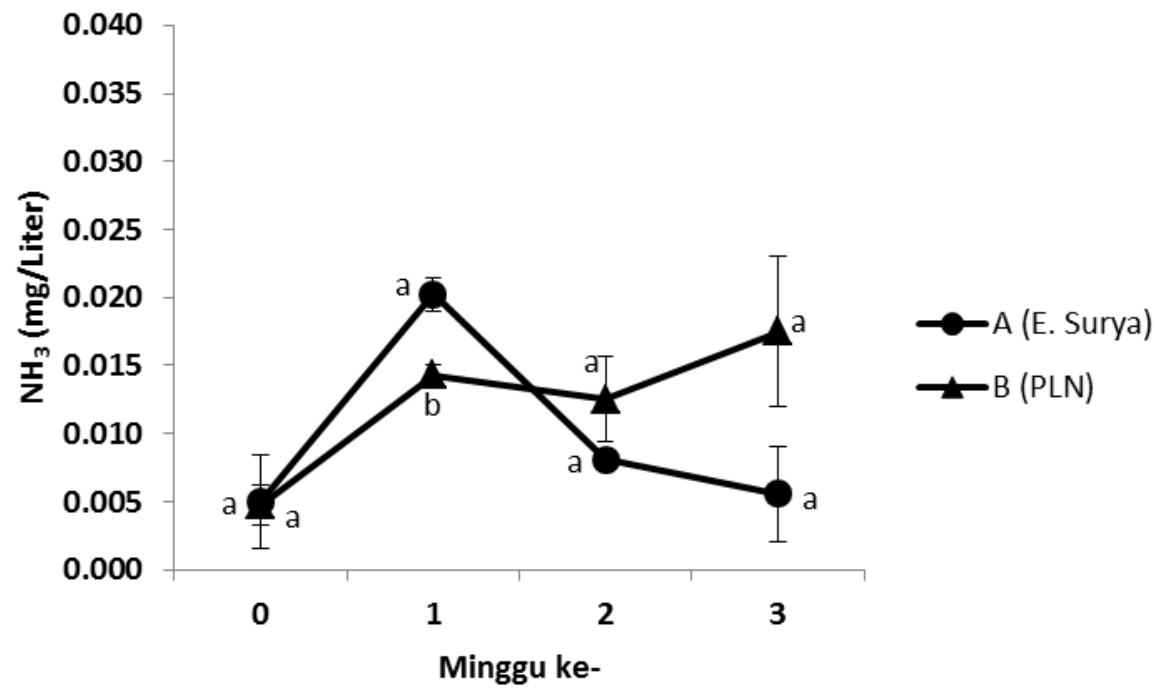

Gambar 7. Grafik amoniak $\left(\mathrm{NH}_{3}\right)$ media pemeliharaan udang vaname pada minggu ke-0, 1, 2, dan 3 dengan sumber energi yang berbeda. Huruf kecil yang berbeda dalam grafik menunjukkan beda nyata $(\mathrm{p}<0,05)$. 
Figure 7. Graph of ammonia (NH3) concentration in water during vaname shrimp rearing at $0,1,2$, and 3 weeks with different energy sources. Different lowercase letters in the graph indicates significant difference $(p<0.05)$.

Berdasarkan Gambar 7, dapat diketahui bahwa $\mathrm{NH}_{3}$ mengalami kenaikan pada minggu pertama. Kemudian $\mathrm{NH}_{3}$ air dari perlkuan menggunakan sumber energi surya terus mengalami penurunan hingga akhir penelitian. Sedangkan $\mathrm{NH}_{3}$ air dari perlakuan menggunakan sumber energi PLN mengalami penurunan pada minggu ke-2, dan kembali naik pada minggu ke-3.
Hasi analisis ragam menunjukkan Kondisi $\mathrm{NH}_{3}$ antar perlakuan pada minggu ke-1 berbeda nyata $(\mathrm{p}<0,05)$, sedangakan pada minggu ke 0,2 dan 3 tidak berbeda nyata $(\mathrm{p}>0,05)$.

\section{Tingkat Kelangsungan Hidup (Survival Rate, SR)}

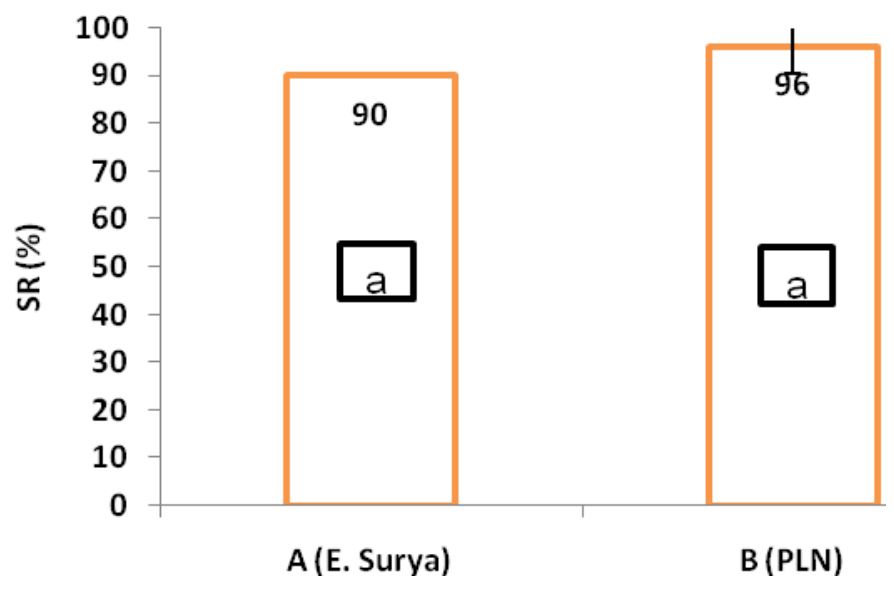

Gambar 8. Grafik kelangsungan hidup (SR) udang vaname selama 20 hari pemeliharaan. Huruf kecil yang berbeda dalam grafik menunjukkan beda nyata $(\mathrm{p}<0,05)$.

Figure 8. Survival Rate (SR) of vaname shrimp after rearing for 20 days. Different lowercase letters in the graph indicates significant difference $(p<0.05)$.

Hasil penelitian menunjukkan bahwa SR udang vaname selama pemeliharaan 20 hari tidak berbeda nyata $(p>0,05)$ antara perlakuan sumber energi surya dengan sumber energi PLN. SR udang vaname pada perlakuan sumber energi surya sebesar $90 \pm 0,00 \%$, sedangkan pada perlakuan sumber energi PLN sebesar $96 \pm 5,60 \%$.

Laju Pertumbuhan Spesifik (Specific Growth Rate, SGR) 


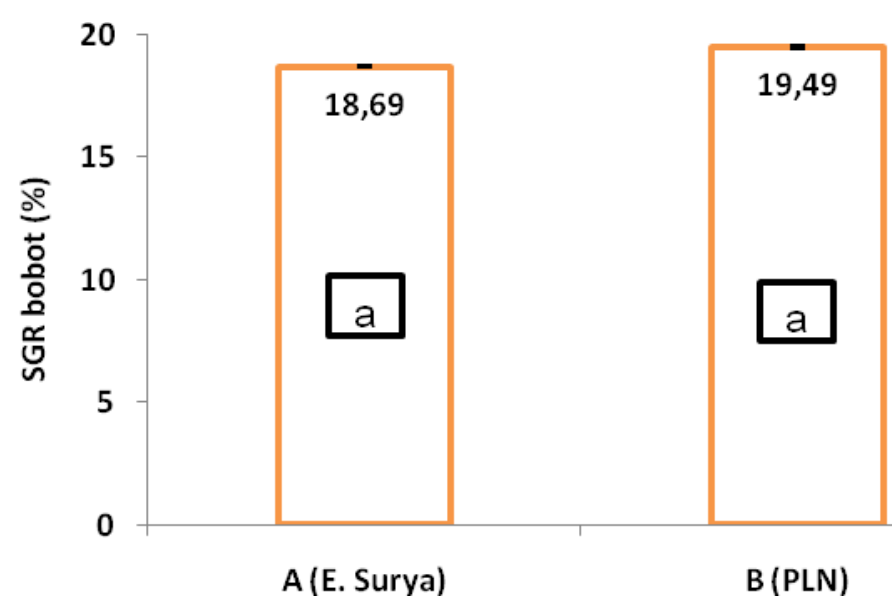

Gambar 9. Laju pertumbuhan spesifik (SGR) bobot udang vaname selama 20 hari pemeliharaan. Huruf kecil yang berbeda dalam grafik menunjukkan beda nyata $(\mathrm{p}<0,05)$.

Figure 9. Specific growth rate (SGR) of vaname shrimp weights after rearing for 20 days. Different lowercase letters in the graph indicates significant difference ( $p$ $<0.05)$.

Hasil penelitian menunjukkan bahwa SGR bobot udang vaname tidak berbeda nyata $(\mathrm{p}>0,05)$ antara perlakuan sumber energi surya dengan sumber energi PLN. SGR udang vaname pada perlakuan sumber energi surya dan PLN masing-masing sebesar $18,69 \pm 0,04 \%$ dan $19,49 \pm 0,09 \%$.

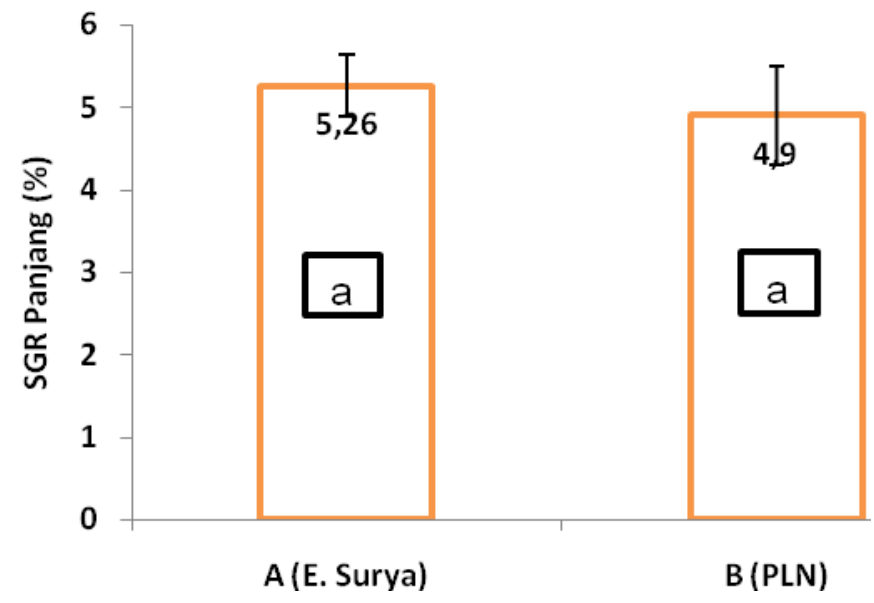

Gambar 10 Grafik laju pertumbuhan spesifik (SGR) panjang udang vaname. Huruf kecil yang berbeda dalam grafik menunjukkan beda nyata $(\mathrm{p}<0,05)$.

Figure $10 \quad$ Specific growth rate (SGR) of shrimp vaname total length. Different lowercase letters in the graph indicates significant difference $(p<0.05)$.

Hasil penelitian menunjukan bahwa laju pertumbuhan spesifik (SGR) panjang udang vaname tidak berbeda nyata $(\mathrm{p}>0,05)$ antara perlakuan sumber energi surya dengan sumber energi PLN. SGR panjang udang vaname pada perlakuan sumber energi surya dan PLN masing-masing sebesar $5,26 \pm 0,37 \%$ dan $4,9 \pm 0,60 \%$.

\section{Pembahasan}

DO dalam air bersumber dari difusi oksigen yang terkandung di udara ke dalam air, baik 
secara alami maupun karena proses aerasi, serta hasil fotosintesis biota nabati berklorofil. Dinamika DO melibatkan interaksi kompleks antara beberapa komponen kimia, biokimia, dan proses transfer massa. Tiga faktor yang mempengaruhi konsentrasi DO dalam perairan adalah fotosintesis, respirasi dan reaerasi (Gonzalez et al. 2014). Berdasarkan Gambar 2, dapat diketahui bahwa , level DO mempunyai kecenderungan lebih rendah pada awal pemeliharaan. Hal ini dapat terjadi karena kelarutan oksigen pada air memerlukan waktu kontak. Semakin lama proses aerasi maka waktu kontak oksigen dengan air semakin besar, sehingga kelarutannya berangsur-angsur akan meningkat. Faktor lain adalah karena persentase pakan yang terbuang lebih banyak pada awal penelitian. Hal ini karena pemberian pakan diberikan 2 ppm dari awal hingga akhir pemeliharaan. Pakan yang terbuang ini mengandung bahan organik yang tinggi. Menurut Santa dan Vinatea (2007), proses dekomposisi bahan organik dalam air membutuhkan oksigen yang cukup tinggi. Hal ini akan menyebabkan berkurangnya konsentrasi oksigen terlarut di dalam air.

Konsentrasi DO pada masing-masing perlakuan memiliki kisaran antara 7-8 $\mathrm{mg} /$ Liter (energi surya) dan 6,8-8 $\mathrm{mg} /$ Liter (PLN). Konsentrasi oksigen terlarut yang disarankan untuk budidaya udang adalah > 5 mg/L (Boyd dan Tucker 1998; Budiardi 2008). Hal ini, menunjukkan nilai DO masih memenuhi syarat untuk budidaya postlarva udang vaname. Tingginya nilai DO ini memungkinkan padat tebar postlarva udang pada kegiatan budidaya masih bisa ditingkatkan. Penurunan DO pada perlakuan sumber PLN pada hari ke19 sebesar 6,8 mg/Liter disebabkan karena high-blow tidak dapat menyuplai oksigen karena mati listrik. Penurunan DO pada hari ke-19 relatif lebih besar jika dibandingkan dengan DO pada mati listrik hari ke-4 dan 7. Hal ini disebabkan mati listrik yang terjadi pada hari ke-19 berlangsung lebih lama.

Oksigen terlarut berhubungan erat dengan suhu, semakin tinggi suhu maka semakin kecil kelarutan oksigen dalam air dan proses biologi serta kimia akan meningkat, sehingga konsumsi oksigen akan meningkat pula (Seginer dan Mozes 2012). Tampak pada Gambar 2 dan 4, pada saat suhu naik di minggu ke-1, di saat yang sama DO mengalami penurunan. Pada minggu ke-2 suhu mengalami penurunan sedangkan disaat yang sama, DO meningkat. Pada minggu ke-3 suhu tetap mengalami penurunan, sedangkan DO cukup stabil, kecuali DO pada perlakuan sumber energi PLN. DO mengalami penurunan disebabkan oleh high-blow yang berhenti mensuplai oksigen ke media pemeliharaan. High-blow tidak beroperasi disebabkan karena listrik dari sumber energi PLN mengalami pemadaman.

Kondisi pH dapat mempengaruhi kemampuan untuk mempertahankan homeostasis, metabolisme, pertumbuhan, kelangsungan hidup, kapasitas osmotik dan sistem kekebalan tubuh udang penaeid, seperti L. vannamei, dan krustasea lainnya (Zhou et al. 2009). Kondisi pH selama penelitian berkisar antara 8,13 $\pm 0,02$ $8,42 \pm 0,14$ (sumber energi surya) dan $8,25 \pm 0,06-8,48 \pm 0,05 \quad$ (PLN). Menurut Budiardi (2008), kisaran $\mathrm{pH}$ yang optimum bagi udang adalah 7,5-8,5. Secara keseluruhan, nilai $\mathrm{pH}$ selama penelitian masih sesuai untuk pertumbuhan optimum udang vaname. Penggunaan sumber energi yang berbeda pada pemeliharaan postlarva udang vaname tidak menunjukkan perbedaan kondisi $\mathrm{pH}$ selama penelitian. Hal ini karena level oksigen selama penelitian masih $>5 \mathrm{mg} / \mathrm{L}$, sehingga proses metabolisme udang vaname dan kebutuhan oksigen degrrdasi bahan organik (feces, sisa pakan) oleh mikroorganisme berjalan dengan baik. Kondisi pH selama penelitian cenderung stabil disebabkan penelitian dilakukan secara indoor. Pada penelitian

Kondisi Kualitas Air Dan Respons Pertumbuhan Pada Pemeliharaan Postlarva Udang Vaname Litopenaeus Vannamei Menggunakan Sumber Energi Surya - Kukuh Adiyana, Rahma Vida Anandasari, Tuti Wahyuni, dan Lolita Thesiana 
secara indoor, faktor eksternal seperti hujan yang dapat mempengaruhi perubahan $\mathrm{pH}$ dapat ditiadakan. Kecenderungan penurunan $\mathrm{pH}$ terjadi disebabkan karena terakumulasinya bahan organik (sisa pakan, feces) selama pemeliharaan (Boyd 1989).

Kondisi $\mathrm{CO}_{2}$ pada media pemeliharaan dengan sumber energi yang berbeda secara keseluruhan bernilai $0 \mathrm{mg} / \mathrm{L}$. Menurut Hardjojo (2005) pada $\mathrm{pH}>8$ dan karbonat hardness bernilai 1 , konsentrasi $\mathrm{CO}_{2}$ bernilai $0 \mathrm{mg} /$ Liter. Kondisi salinitas selama penelitian pada kedua sumber energi yang berbeda berkisar antara 29-30 ppt. Menurut Boyd (1989), kondisi salinitas optimum udang vaname adalah $15 \mathrm{ppt}-25$ ppt, namun menurut $\mathrm{Li}$ et al (2007), peningkatan salinitas sampai 30-45 ppt tidak berpengaruh terhadap pertumbuhan udang vaname. Hal ini menunjukkan udang vaname mempunyai toleransi nilai salinitas yang cukup luas.

Kondisi amoniak pada sumber energi surya berkisar antara 0,003-0,021 $\mathrm{mg} / \mathrm{L}$, sedangkan pada sumber energi PLN berkisar antara 0,004 -0,021 $\mathrm{mg} /$ Liter. Menurut Budiardi (2008), amoniak untuk pemeliharaan udang yang optimum adalah $<0,10 \mathrm{mg} / \mathrm{L}$. Secara keseluruhan, kondisi amoniak selama penelitian pada sumber energi yang berbeda masih memenuhi syarat. Konsentrasi amoniak dipengaruhi oleh suhu, oksigen dan $\mathrm{pH}$. Semakin tinggi suhu, amoniak akan mengalami peningkatan (Boyd 1989). Berdasarkan Gambar 5, suhu harian rata-rata meningkat pada minggu ke-1, yang diikuti juga dengan kenaikan amoniak pada minggu yang sama (Gambar 7). Konsentrasi amoniak mengalami penurunan pada minggu ke-2 dan 3 seiring dengan penurunan nilai $\mathrm{pH}$ (Gambar 6) pada perlakuan sumber energi surya. Meskipun demikian, pada minggu ke-2 dan -3, pH pada sumber energi PLN mengalami penurunan, sedangkan amoniak mengalami kenaikan. Hal ini dapat karena terjadi mati listrik pada minggu ke-2 dan -3 , yang menyebabkan pasokan oksigen terhenti. Turunnnya konsentrasi DO dalam air menyebabkan proses nitrifikasi tidak berjalan dengan baik, sehingga konsentrasi amoniak mengalami peningkatan.

SR dan SGR udang vaname menggunakan sumber energi surya tidak berbeda nyata dengan sumber energi PLN. Hal ini disebabkan kondisi oksigen selama penelitian pada kedua sumber energi yang berbeda masih optimal, yaitu $>5 \mathrm{mg} / \mathrm{L}$. Pemadaman listrik yang terjadi hanya menyebabkan DO turun hingga $6,8 \mathrm{mg} / \mathrm{L}$, sehingga tidak berpengaruh terhadap SR dan SGR udang vaname.

\section{KESIMPULAN DAN SARAN}

Penggunaan sumber energi surya pada pemeliharaan postlarva udang vaname tidak berpengaruh terhadap kondisi kualitas air dan respons pertumbuhan udang. Hal ini disebabkan pemadaman listrik oleh PLN hanya menyebabkan penurunan konsentrasi DO sampai 6,8 $\mathrm{mg} / \mathrm{L}$, dimana pada konsentrasi ini respons pertumbuhan udang masih dalam kondisi optimal. Pada konsentrasi DO sebesar $6,8 \mathrm{mg} / \mathrm{L}$, proses degradasi bahan organik (sisa pakan, feces) dapat berjalan optimal sehingga tidak memberikan korelasi pengaruh terhadap parameter kualitas air lainnya. Ditinjau dari kondisi kualitas air dan respons pertumbuhan, sumber energi surya merupakan salah satu alternatif teknologi terbarukan yang layak untuk budidaya postlarva udang vaname.

\section{DAFTAR PUSTAKA}

[APHA] American Public Health Association, (1990). Standard Methods for The Examination of Water and Waste Water. $20^{\text {th }}$ edition. Washington DC (US): APHA Pr.

Bakhiyi B, Labreche F, Zayed J. (2014). The photovoltaic industry on the path to a sustainable future Environmental and occupational health issues. Environment International 73:224-234.

Boyd CE. (1989). Water Quality Management and Aeration in Shrimp Farming. Ala. Agr. Exp. Sta., Auburn 
Univ., Ala., Fisheries and Allied Aquacultures Dept.Ser. No.2. 83 pp.

Boyd CE, Tucker CS. (1998). Pond aquaculture water quality management. New York (US): Springer Science+Business Media.

Budiardi T. (2008). Keterkaitan produksi dengan beban masukan bahan organik pada sistem budidaya intensif udang vaname (Litopenaeus vannamei Boone 1931). [Disertasi]. Sekolah Pascasarjana, Institut Pertanian Bogor. Bogor.

Fara L, Yamaguchi M. (2013). Advanced Solar Cell Materials, Technology, Modeling and Simulation. United States: Engineering Science Reference.

Food and Agriculture Organization of the United Nations (FAO). (2012). Litopenaeus vannamei. In M. Briggs (Ed.),Cultured aquatic species information programme. Rome: FAO Fisheries and Aquaculture Department.

Gonzalez JCC, Parga MDCC, Cortes JA. (2014). Photosynthesis, respiration and reaeration in a stream with complex dissolved oxygen pattern and temperature dependence. Ecological Modelling 273:220-227.

Kumar A, Moulick S, Mal BC. (2013). Selection of aerators for intensive aquacultural pond. Aquacultural Engineering 56:71- 78 .

Li E, Chen L, Zeng C, Chen X, Yu N, Lai Q, Qin JG. (2007). Growth, body composition, respiration and ambient ammonia nitrogen tolerance of the juvenile white shrimp, Litopenaeus vannamei, at different salinities. Aquaculture 265:385-390.

Li L, Boyd CE, Odom J. (2014). Identification of Pacific white shrimp (Litopenaeus vannamei) to rearing location using elemental profiling. Food Control 45:70-75.

Moheimani NR, Parlevliet D. (2013). Sustainable solar energy conversion to chemical and electrical energy.
Renewable and Sustainable Energy

Reviews 27:494-504.

Nuhman. (2009). Pengaruh prosentase pemberian pakan terhadap kelangsungan hidup dan laju pertumbuhan udang Vannamei (Litopenaeus vannamei). Jurnal Ilmiah Perikanan dan Kelautan Vol. 1, No. 2, Nopember.

Renewable Energy Policy Network for the 21st Century (REN). (2013). Renewables 2013. Global status report.

http://www.ren21.net/Portals/0/docu ments/Resources/ GSR/2013/GSR2013_lowres.pdf, diakses pada tanggal 23 Desember 2014.

Samocha TM, Lawrence AL. (1992). Shrimp nursery system and management. in: Wyban J. Proceedings of the Special Session on Shrimp Farming. USA: World Aquaculture Society. hlm. 88 .

Santa KD, Vinatea L. (2007). Evaluation of respiration rates and mechanical aeration requirements in semiintensive shrimp Litopenaeus vannamei culture ponds. Aquacultural Engineering 36:73-80.

Seginer I, Mozes N. (2012). A note on oxygen supply in RAS: The effect of water temperature. Aquacultural Engineering 50:46- 54.

Solanki Y, Jetani KL, Khan SI, Kotiya AS, Makawana NP, Rather MA. (2012). Effect of Stocking Density on Growth and Survival Rate of Spiny Lobster Panulirus polyphagus in Cage Culture System. International Journal of Aquatic Science. 3(1):314.

Solarbuzz. 2012 Modules pricing. Retail price summary. March (2012). http://www.solarbuzz.com/facts-andfigures/retail-price environment/module-prices, diakses pada tanggal 23 Desember 2014.

Zhou J, Wang WN, Wang A, He W, Zhou Q, Liu Y, Xu J. (2009). Glutathione

Kondisi Kualitas Air Dan Respons Pertumbuhan Pada Pemeliharaan Postlarva Udang Vaname Litopenaeus Vannamei Menggunakan Sumber Energi Surya - Kukuh Adiyana, Rahma Vida Anandasari, Tuti Wahyuni, dan Lolita Thesiana 
S-transferase in the white shrimp

Litopenaeus vannamei:

Characterization and regulation

under $\mathrm{pH}$ stress. Comparative

Biochemistry and Physiology, Part C

150: 224-230. 